\title{
IgE Receptor-Bearing Lymphocytes in Allergic and Nonallergic Children
}

\author{
KWANG-MYONG KIM, MITSUFUMI MAYUMI, YOSHITAKA IWAI, MAYUMI TANAKA, \\ SETSUKO ITO, KEISUKE SHINOMIYA, AND HARUKI MIKAWA \\ Department of Pediatrics, Faculty of Medicine, Kyoto University, Kyoto, Japan
}

\begin{abstract}
Using a monoclonal anti-human IgE receptor $(F c \in R$ ) antibody, the percentage of $F c \in R(+)$ cells among peripheral blood lymphocytes in children with or without allergic disorders was determined. The percentage of $F c \in R(+)$ cells in 63 nonallergic children was $4.3 \pm 1.5 \%$, which did not vary with age and was equal to that of adults $(4.2 \pm 1.2 \%)$. Allergic younger children $(0-2 \mathrm{yr})$ showed a significantly higher percentage of $F c \in R(+)$ cells $(7.7 \pm$ $3.0 \%)$ than nonallergic younger children $(0-2 \mathrm{yr})(4.0 \pm$ $1.3 \%, p<0.001$ ). Similarly, in allergic younger children, serum IgE levels (geometric mean $=58.9 \mathrm{IU} / \mathrm{ml}$ ) were also significantly higher than those of nonallergic younger children $($ geometric mean $=2.0 \mathrm{IU} / \mathrm{ml})(p<0.01)$. A positive correlation between the percentages of $F c \in R(+)$ cells and serum IgE levels was observed (Spearman rank $=0.88, p$ $<0.01)$ ) in eight allergic younger children $(0-2$ yr) with serum IgE levels higher than $100 \mathrm{IU} / \mathrm{ml}$. The increase in the percentage of $F c \in R(+)$ cells in allergic younger children $(0-2$ yr) was not a secondary phenomenon caused by serum IgE because serum IgE levels in these children were much lower than the concentration at which IgE enhance $F c \in R$ expression on lymphocytes. In conclusion, $\mathrm{Fc} \in \mathbf{R}(+)$ lymphocytes may play a regulatory role in $\mathrm{IgE}$ synthesis in allergic younger children (0-2 yr). (Pediatr Res 24: 254$257,1988)$
\end{abstract}

\section{Abbreviations}

$F c \in R$ receptor for the $F c$ portion of $\operatorname{IgE}$

MNC, mononuclear cells

PBS, phosphate-buffered saline

FCS, fetal calf serum

FITC, fluorescein isothiocyanate

PE, phycoerythrin

RAST, radio-allergo-sorbent test

Inasmuch as $\mathrm{F}_{\mathrm{C}} \mathrm{R} \mathrm{R}$ on lymphocytes were first described in 1976 (1), attention was focused on their regulatory role in IgE synthesis. Indeed, the fact that the percentage of $F c \in R$-bearing $[\mathrm{Fc} \epsilon \mathrm{R}(+)]$ lymphocytes is higher in individuals with hyper-IgE states $(2,3)$ suggests the possible participation of $F c \epsilon R(+)$ cells in the regulation of $\operatorname{IgE}$ synthesis.

The function of $F c \in R(+)$ cells in animals is well known. Rats infected with the parasite Nippostrongylus brasiliensis show not only a.rise in serum IgE levels, but also in the percentage of

Received November 10, 1987; accepted April 18, 1988.

Correspondence Kwang-Myong Kim, M.D., Department of Pediatrics, Faculty of Medicine, Kyoto University, Shogoinkawahara-cho 54, Sakyo-ku, Kyoto 606, Japan.

Supported by grants from the Ministry of Health and Welfare, and the Ministry of Education, Science and Culture, Japan.
$F c \in R(+)$ cells $(4,5)$. Using this model, it was noted that $F c \epsilon R(+)$ $T$ cells secrete a soluble factor with an affinity for $\operatorname{IgE}(\operatorname{IgE}-$ binding factor) which enhances IgE production (IgE-potentiating factor) (6). Thus, it was demonstrated that $F c \in R(+) T$ cells play an essential role in rat $\operatorname{IgE}$ synthesis.

In humans, $\mathrm{Fc} \epsilon \mathrm{R}(+) \mathrm{T}$ cells producing an IgE-potentiating factor were obtained from patients with the hyper-IgE syndrome, in whom both the percentage of $F c \in R(+)$ cells and serum $\operatorname{IgE}$ levels are increased (7). Although the function of $F c \epsilon R(+) B$ cells, which occupy the major part of $F c \epsilon R(+)$ lymphocytes, was not clarified in animals, it was demonstrated that, in humans, these cells also enhance IgE synthesis by the secretion of an IgEpotentiating factor $(8,9)$. These results suggest that, as in rats, human $\mathrm{IgE}$ synthesis might be regulated by $F c \in R(+)$ lymphocytes.

Fc $\epsilon \mathrm{R}$ is induced on lymphocytes by soluble $\mathrm{T}$ cell factors (1012); however, $\operatorname{IgE}$ can also enhance the expression of $F c \epsilon R$ on lymphocytes $(5,13,14)$. It is possible, therefore, that the increase in the percentage of $F c \epsilon R(+)$ cells in patients of hyper-IgE state, whose serum IgE levels are comparable to the concentration at which the enhancing activity of $\operatorname{IgE}$ in $\mathrm{Fc} \epsilon \mathrm{R}$ expression appeared in vitro, is caused secondarily by serum IgE. To support the IgEpotentiating activity of $F c \in R(+)$ cells in vivo, it is important to demonstrate that the increase in the percentage of $F c \in R(+)$ cells is a primary event.

Despite the well-known fact that serum $\operatorname{IgE}$ levels rise and allergic disorders develop during childhood, there are no reports on the percentage of $F c \in R(+)$ lymphocytes in children. Therefore, we examined the percentage of $F c \in R(+)$ cells in children, based on the assumption that, if $\mathrm{Fc} \in \mathrm{R}(+)$ cells enhance IgE production, an increase in the percentage of $F c \in R(+)$ cells should be observed in younger allergic children whose serum IgE levels are still lower than those of older allergic individuals.

\section{MATERIALS AND METHODS}

Donors. Allergic disorders were diagnosed when at least one of the following was found in children with typical symptoms: 1 ) the presence of other allergic patients in their family; 2) positive results in RAST or skin tests; 3) serum IgE levels higher than the mean $+1 \mathrm{SD}$ of those of nonallergic children in this study. Actually, levels were set at $10 \mathrm{IU} / \mathrm{ml}$ in infants, $100 \mathrm{IU} / \mathrm{ml}$ in 1 to 2 -yr-old children, and $400 \mathrm{IU} / \mathrm{ml}$ in older children (3-15 yr).

The allergic group consisted of 76 children (46 males and 30 females); 51 had bronchial asthma with or without other allergic disorders and 25 had atopic dermatitis only. Of these children $90.8 \%(69 / 76), 82.9 \%(63 / 76)$, and $75.0 \%(57 / 76)$ met the diagnostic criterion for 1$), 2$ ), and 3), respectively. A total of $92.1 \%(70 / 76)$ of the children filled the criterion for 2) and/or $3)$. Patients medicated continuously with systemic corticosteroids were excluded because of their effect of reducing Fc $\epsilon$ R on lymphocyte $(2,10,15)$.

The nonallergic group consisted of 63 children ( 34 males and 
29 females) who had no allergic, immunological, or hematological problems.

Blood was obtained during routine blood examinations using a three-way connector, after informed consent had been obtained from their parents and, if the children were old enough, from the patients themselves. Blood of normal and allergic adults was drawn from volunteers in our laboratory. These samples were collected between November 1986 and June 1987.

Measurement of serum IgE levels. Serum IgE levels in 74 allergic and 37 nonallergic children were determined using Pharmacia IgE RIA kits, generously provided by Shionogi and Company Ltd., Osaka, Japan. These kits are unaffected by serum agents that normally interfere with the detection of IgE. The measurable range is from $10-2000 \mathrm{IU} / \mathrm{ml}$ using the standard procedure and from 1-40 IU/ml using the high sensitivity procedure.

Preparation of lymphocytes. Peripheral blood MNC were collected by the previously described method (16), except that heparinized blood was incubated with silica particles (KAC 2 , Japan Immunoresearch Laboratories, Takasaki, Japan) at $37^{\circ} \mathrm{C}$ for $60 \mathrm{~min}$ before being layered over Ficoll-Paque (Pharmacia Fine Chemicals AB, Uppsala, Sweden) to remove phagocytes. The percentage of monocytes in MNC was less than $5 \%$.

Cells and antibodies. The mouse IgG2b monoclonal antihuman FceR (CD23) antibody (H107) (17) and the Fc $\epsilon \mathrm{R}(+)$ human B cell line (RPMI 8866) were kindly provided by Dr. J. Yodoi (Institute for Immunology, Kyoto University, Japan). Purified mouse myeloma IgG2b protein which did not react to the antigens on human lymphocytes was purchased from Miles Scientific Div., Naperville IL. The FITC-conjugated goat antimouse IgG antibody was obtained from Tago Inc., Burlingame, CA. Monoclonal mouse anti-T3 (pan-T cell antigen) and antiB1 (pan-B cell antigen) antibody conjugated with PE was obtained from Coulter Immunology, Hialeah, FL.

Immunofluorescent analysis. MNC were suspended in a staining solution (PBS plus $3 \%$ FCS and $0.1 \%$ sodium azide) at a concentration of $1 \times 10^{6}$ cells $/ \mathrm{ml}$. The cell suspension was placed in micro-glass tubes (Nichiden, Kobe, Japan) in volumes of 750 $\mu \mathrm{l} /$ tube, and pelleted by centrifugation. The cells were incubated with $20 \mu \mathrm{l}$ of $20 \mu \mathrm{g} / \mathrm{ml} \mathrm{H} 107$ antibody at $4^{\circ} \mathrm{C}$ for $30 \mathrm{~min}$ (first incubation). After being washed twice with staining solution and pelleted, the cells were incubated again with $20 \mu \mathrm{l}$ of $20 \mu \mathrm{g} / \mathrm{ml}$ FITC-conjugated goat anti-mouse IgG antibody at $4^{\circ} \mathrm{C}$ for 30 min (second incubation). The cells were then washed twice and resuspended in $0.5 \mathrm{ml}$ of staining solution.

Controls for each sample were prepared by the same procedure except that the first incubation was performed with $20 \mu \mathrm{l}$ of 20 $\mu \mathrm{g} / \mathrm{ml}$ of nonrelated mouse myeloma IgG2b protein instead of the $\mathrm{H} 107$ antibody.

The percentage of fluorescence-positive cells was determined by flow cytometry (FACS 440, Becton-Dickinson, Mountain View, CA). Under these conditions, more than $90 \%$ of RPMI 8866 cells were fluorescence positive and the percentage of nonspecifically stained MNC was usually less than $1 \%$. From the percentage of fluorescence-positive cells in each sample, that of each control sample, namely that of nonspecifically stained cells, was subtracted. The difference was recorded as the percentage of $\mathrm{Fc} \in \mathrm{R}(+)$ cells.

Double staining analysis. Some MNC samples, which had already gone through both the first incubation with $\mathrm{H} 107$ antibody and the second incubation with FITC-conjugated antimouse IgG antibody according to the previously described procedure, were further incubated with PE-conjugated anti-T3 antibody or anti-B1 antibody at $4^{\circ} \mathrm{C}$ for $30 \mathrm{~min}$ (third incubation). In control samples, MNC were not incubated with $\mathrm{H} 107$ antibody, but with nonrelated mouse IgG2b protein during the first incubation.

Analysis of data. Data on the percentage of $F c \in R(+)$ cells are presented as the mean \pm 1 SD. Data on serum IgE were first transformed logarithmically and then presented as the geometric mean and a range of $\pm 1 \mathrm{SD}(18)$. The statistical significance of the differences in the percentage of $F c \in R(+)$ cells was evaluated using a $t$ test. Although the data are not shown, the significance was also confirmed using a Wilcoxon rank-sum test. The statistical significance of the differences in $\mathrm{IgE}$ values was evaluated by Wilcoxon rank-sum test. In some cases, the Spearman rank correlation coefficient between the percentage of $F c \in R(+)$ cells and the serum IgE level was determined. For convenience in calculation, serum $\mathrm{IgE}$ values lower than $1 \mathrm{IU} / \mathrm{ml}$ were all approximated at $0.5 \mathrm{IU} / \mathrm{ml}$.

\section{RESULTS}

$F c \in R(+)$ lymphocytes in children. The percentage of $F \subset \in R(+)$ lymphocytes in children without allergic disorders showed no age-dependent variations and was the same as that of adults (Fig. 1).

In allergic children, the percentage of $F c \in R(+)$ cells was higher in children up to 2 yr of age, after which it decreased to almost the same level as nonallergic children (Fig. 1). Allergic children, therefore, were divided into two groups; those more than and those less than 2 yr old. For statistical purposes, nonallergic children were also divided into the same two groups.

Allergic younger children ( $0-2$ yr) had the highest percentage of $F c \in R(+)$ cells, significantly higher than nonallergic younger children $(0-2 \mathrm{yr})(p<0.001)$ or allergic older children $(3-15 \mathrm{yr}$ $(p<0.001)$ (Table 1$)$.

Among older children (3-15 yr), although the percentage of $\mathrm{Fc} \epsilon \mathrm{R}(+)$ cells in allergic children was not significantly different from that of nonallergic children, 11 allergic children did have a

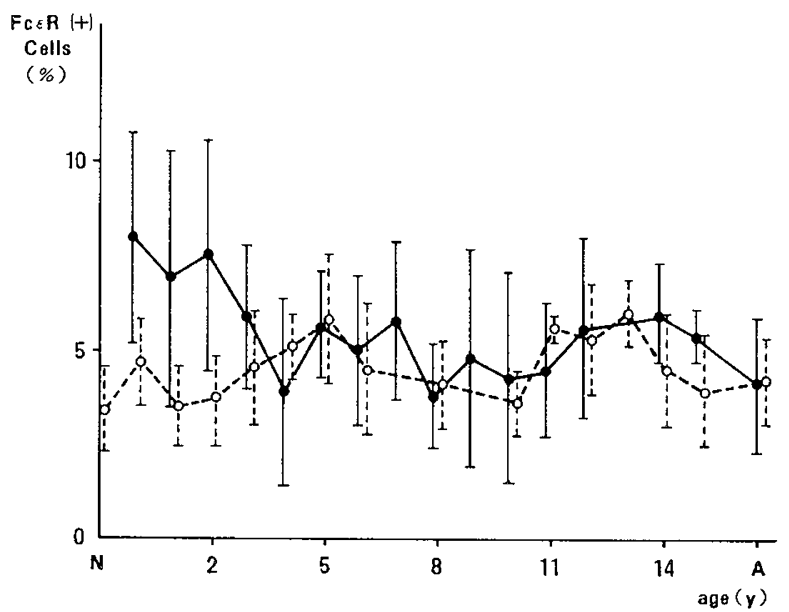

Fig. 1. Variation in the percentage of $\mathrm{Fc} \in \mathrm{R}(+)$ cells with age. $N$, neonates; $A$, adults. The bold solid line shows the mean percentage of $\mathrm{Fc} \in \mathrm{R}(+)$ cells in allergic patients and the bold broken line shows the same in nonallergic subjects. Vertical lines indicate the range of $1 \mathrm{SD}$ in each age group.

Table 1. Percentage of $F C \epsilon R(+)$ cells in allergic and nonallergic children (mean $\pm 1 S D)$

\begin{tabular}{ccc}
\hline Age $(\mathrm{yr})$ & $\begin{array}{c}\text { Allergic } \\
(n)\end{array}$ & $\begin{array}{c}\text { Nonallergic } \\
(n)\end{array}$ \\
\hline $0-2$ & $7.7 \pm 3.0^{*}$ & $4.0 \pm 1.3$ \\
& $(26)$ & $(27)$ \\
$3-15$ & $5.2 \pm 2.5$ & $4.5 \pm 1.6$ \\
& $(50)$ & $(36)$ \\
Total & $6.0 \pm 2.9$ & $4.3 \pm 1.5$ \\
& $(76)$ & $(63)$ \\
Adult & $4.1 \pm 1.8$ & $4.2 \pm 1.2$ \\
& $(9)$ & $(12)$ \\
\hline
\end{tabular}

* Significantly higher than nonallergic younger children $(0-2 \mathrm{yr})(p<$ $0.001)$ and allergic older children $(3-15 \mathrm{yr})(p<0.001)$. 
higher percentage of $F c \in R(+)$ cells than the mean \pm 2 SD of all nonallergic children $(7.3 \%)$.

The percentage of $F c \in R(+)$ cells was not affected by sex, medication containing antiallergic or antiasthmatic agents, or the type or severity of disease (data not shown). The percentage of $F c \in R(+)$ cells in patients with positive family history of allergy alone was not different from that in those with positive RAST or skin tests and/or elevated serum IgE levels (data not shown).

Correlation of percentage of $F c \in R(+)$ cells with serum IgE level. The mean serum IgE level in allergic children rose rapidly in early childhood ( $0-3$ yr), and thereafter stayed constant (Fig. 2).

Serum IgE levels in allergic children of each age group were significantly higher than those in each corresponding nonallergic group (Table 2 ). In general, there is no significant correlation between the percentage of $F c \epsilon R(+)$ cells and the serum IgE level in either allergic or nonallergic children (Table 2). However, in allergic younger children ( $0-2 \mathrm{yr})$ with serum IgE levels higher than $100 \mathrm{IU} / \mathrm{ml}$, the percentage of $\mathrm{Fc} \epsilon \mathrm{R}(+)$ cells did show a positive correlation to the serum IgE level $(n=8$, Spearman rank $=0.88, p<0.01$ ).

Among allergic older children (3-15 yr), nine children with higher percentages of $F c \in R(+)$ cells $(>7.3 \%)$ showed higher serum IgE levels $(1174.9 \mathrm{IU} / \mathrm{ml})$ than the other children $(602.6$ $\mathrm{IU} / \mathrm{ml}, n=37$ ), although the difference was not significant. Two allergic older children (3-15 yr) with extremely high percentages of Fc $\epsilon \mathrm{R}(+)$ cells $(>10.0 \%)$ showed much higher serum $\mathrm{IgE}$ levels $(4365.1 \mathrm{IU} / \mathrm{ml})$ than the other children $(631.0 \mathrm{IU} / \mathrm{ml}, n=44, p$ $<0.05$ ).

Double staining analysis of $F c \in R(+)$ lymphocytes. Lymphocytes from eight younger children $(0-2 \mathrm{yr})$, four allergic and four

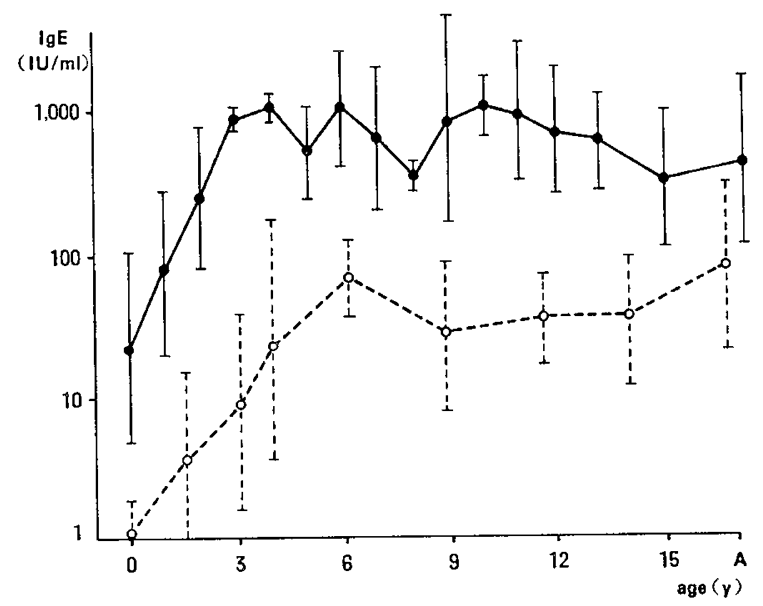

Fig. 2. Variation of serum IgE levels with age. A, adults. The bold solid line shows the mean serum IgE levels in allergic patients and the bold broken line shows the same in nonallergic subjects. The vertical line indicates the range of $1 \mathrm{SD}$ in each age group. nonallergic, were examined by double staining with $\mathrm{H} 107$ antibody and either anti-T3 or anti-B1 antibody (Table 3). The latter are popularly used in discriminating $\mathrm{T}$ and $\mathrm{B}$ cells, respectively, from other cells. Results of this test showed that the percentage of $F c \in R(+)$ B cells was higher in allergic younger children $(0-2$ yr) and was, in fact, comparable to that of all FceR(+) cells. The percentage of $F c \in R(+) T$ cells, however, was very low even in allergic younger children $(0-2$ yr). It was also very low in allergic older children $(3-15 \mathrm{yr})(0.4 \pm 0.2 \%, n=4)$.

\section{DISCUSSION}

This study shows the percentage of $F c \in R(+)$ cells in nonallergic children to be constant in all age groups and equal to that of nonallergic adults (Fig. 1; Table 1). Delespesse et al. (19) reported that the percentage of $F c \epsilon R(+)$ cells in cord blood was the same as that of normal adults. Both studies indicate that the percentage of $F c \in R(+)$ cells in normal individuals is quite stable.

Both the percentage of $F c \in R(+)$ cells and serum IgE levels in allergic younger children $(0-2 \mathrm{yr})$ were significantly higher than those in nonallergic younger children $(0-2 \mathrm{yr})$. A positive correlation between the percentages of $F c \in R(+)$ cells and serum IgE levels was observed in patients with IgE levels higher than 100 $\mathrm{IU} / \mathrm{ml}$. Among allergic older children (3-15 yr), two patients with very high percentage of $\mathrm{Fc} \epsilon \mathrm{R}(+)$ cells $(>10.0 \%)$ showed extremely high serum IgE levels $(>4000 \mathrm{IU} / \mathrm{ml})$. Taking into consideration that $F c \in R(+)$ cells have been shown to enhance IgE production in in vitro experiments $(7-9,20)$, these results may suggest that this enhancing activity also occurs in vivo. These findings may be of value in studying the mechanism of the development of allergic disorders especially in early childhood.

F $\in R$ expression of lymphocytes is also enhanced by $\operatorname{IgE}$ at concentrations of about $10 \mu \mathrm{g} / \mathrm{ml}(5,13,14)$. In previous reports, the increase of $\mathrm{Fc} \in \mathrm{R}(+)$ cells in human peripheral blood lympho-

Table 3. Percentage of FceR (+) $T$ and $B$ cells in younger children $(0-2 y r)$

\begin{tabular}{|c|c|c|c|c|c|}
\hline \multicolumn{3}{|c|}{ Allergic } & \multicolumn{3}{|c|}{ Nonallergic } \\
\hline Patient & $\begin{array}{c}\mathrm{Fc} \in \mathrm{R} \\
(+)^{*} \\
\mathrm{~T} \text { cell }(\%)\end{array}$ & $\begin{array}{c}\mathrm{Fc} \in \mathrm{R} \\
(+) \dagger \\
\mathrm{B} \text { cell }(\%)\end{array}$ & Patient & $\begin{array}{c}\mathrm{Fc} \in \mathrm{R} \\
(+)^{*} \\
\mathrm{~T} \text { cell }(\%)\end{array}$ & $\begin{array}{c}\text { FceR } \\
(+) \dagger \\
\mathrm{B} \text { cell }(\%)\end{array}$ \\
\hline YS & 0.6 & 5.6 & BT & 0.3 & 2.4 \\
\hline MH & 0.0 & 11.6 & $\mathrm{AO}$ & 0.3 & 6.5 \\
\hline MO & 0.1 & 5.7 & TA & 0.0 & 3.1 \\
\hline TK & 0.3 & 8.6 & AA & 0.8 & 6.5 \\
\hline
\end{tabular}

$\begin{array}{cccccc}\text { Total } & 0.3 \pm 0.2 & 7.9 \pm 2.5 & \text { Total } \$ & 0.4 \pm 0.3 & 4.6 \pm 1.9\end{array}$

* Cells bearing both $\mathrm{Fc} \in \mathrm{R}$ and $\mathrm{T} 3$ antigen.

$\dagger$ Cells bearing both $\mathrm{Fc} \in \mathrm{R}$ and $\mathrm{B} 1$ antigen.

$\ddagger$ Presented as mean $\pm 1 \mathrm{SD}$.

Table 2. Serum IgE levels in allergic and nonallergic individuals

\begin{tabular}{|c|c|c|c|c|c|c|}
\hline \multirow[b]{2}{*}{ Age (yr) } & \multicolumn{2}{|c|}{$0-2$} & \multicolumn{2}{|c|}{$3-15$} & \multicolumn{2}{|c|}{ Adult } \\
\hline & Allergic & Nonallergic & Allergic & Nonallergic & Allergic & Nonallergic \\
\hline$n$ & 24 & 12 & 46 & 13 & 7 & 8 \\
\hline $\mathrm{Fc} \in \mathrm{R}(+)^{*}$ cell $(\%)$ & $7.8 \pm 3.0$ & $4.3 \pm 1.4$ & $5.1 \pm 2.5$ & $5.0 \pm 1.5$ & $4.1 \pm 1.5$ & $4.5 \pm 1.2$ \\
\hline $\operatorname{IgE}(\mathrm{IU} / \mathrm{ml}) \dagger$ & $58.9 \ddagger$ & 2.0 & $707.9 \S$ & 15.8 & $338.8 \|$ & 64.6 \\
\hline $1 \mathrm{SD}$ range & $9.1-380.2$ & $0.7-5.8$ & $245.0-2041.7$ & $3.8-66.1$ & $97.7-1174.9$ & $20.0-208.9$ \\
\hline Spearman rank & 0.09 & -0.23 & 0.20 & 0.24 & 0.04 & 0.54 \\
\hline
\end{tabular}

* Presented as mean $\pm 1 \mathrm{SD}$.

$\dagger$ Presented as geometric mean and $1 \mathrm{SD}$ range.

$¥$ Significantly higher than nonallergic younger children $(0-2$ yr $)(p<0.01)$ and all nonallergic children $(0-15$ yr $)(p<0.01)$.

$\S$ Significantly higher than nonallergic older children $(3-15 \mathrm{yr})(p<0.01)$ and nonallergic adults $(p<0.01)$.

II Significantly higher than nonallergic adults $(p<0.05)$.

Spearman rank correlation coefficient between the percentages of $F c \in R(+)$ cells and serum IgE levels. 
cytes was always accompanied by extremely high serum $\operatorname{IgE}$ levels $(>10,000 \mathrm{IU} / \mathrm{ml})(2,3)$ that were comparable to the concentration at which $F c \in R$ expression is enhanced by $\operatorname{IgE}$. There was still, therefore, the possibility that this increase in the percentages of $F c \in R(+)$ cells was caused by serum IgE. In our study, however, serum IgE levels of allergic younger children $(0-$ $2 \mathrm{yr})$ were much lower than this critical IgE concentration. The results suggest that an increase in the percentage of $F c \in R(+)$ cells is not a secondary phenomenon resulting from an elevation of IgE levels but a primary event preceding an increase in $\operatorname{IgE}$ concentration. This finding favors the up-regulating function of $\mathrm{F} c \in \mathrm{R}(+)$ cells in in vivo IgE synthesis.

Serum IgE levels rapidly increase with age up to $3 \mathrm{yr}$, after which there is no apparent increase (Fig. 2). The prevalent rate of antigen-specific IgE antibody against common allergens such as eggs and mites in allergic children, as determined by RAST score, also rose promptly up to $2 \mathrm{yr}$ of age. Thereafter, the levels either continued to rise slowly to a maximum or, in the case of food allergens, began to decline (Ito S, Mikawa $\mathrm{H}$, unpublished data). These findings suggest that the sensitization to allergens is almost complete by 2 or 3 yr of age. Inasmuch as an increase in the percentage of $\mathrm{Fc} \epsilon \mathrm{R}(+)$ cells was observed only in allergic younger children $(0-2 \mathrm{yr})$ in whom intensive sensitization might be occurring, it may be a reaction related to this sensitization. Activation of $\mathrm{T}$ cells by allergens during the sensitizing process may cause the increase in $F c \in R(+)$ cells because $F c \in R$ was induced on lymphocytes by soluble factors secreted by activated $T$ cells (10-12). Additional investigation is required in order to confirm this assumption.

In our study, the percentage of $F c \in R(+) T$ cells was too low to draw any conclusions on their behavior. However, it seems that the percentage of $F c \in R(+) T$ cells did not increase even in allergic younger children $(0-2 \mathrm{yr})$ despite a significant increase in the percentage of $F c \epsilon R(+) B$ cells. In animals, the function of $\mathrm{Fc} \in \mathrm{R}(+) \mathrm{B}$ cells is presently unclear. In humans, however, Fc $\epsilon R(+) B$ cells, as well as $F c \in R(+) T$ cells, have been shown to have an up-regulating effect on IgE production by secreting an IgE-potentiating factor $(8,9)$. If $\mathrm{Fc} \in \mathrm{R}(+)$ lymphocytes indeed enhance IgE synthesis, such an effect in allergic younger children may be due specifically to $F c \epsilon R(+) B$ cells.

\section{REFERENCES}

1. Gonzalez-Molina A, Spiegelberg HL 1976 Binding of IgE myeloma proteins to human cultured lymphoblastoid cells. J Immunol 1 17:1838-1845

2. Spiegelberg HL, O'Connor RD, Simon RA, Mathison DA 1979 Lymphocytes with immunoglobulin $\mathrm{E} \mathrm{FC}$ receptors in patients with atopic disorders. J Clin Invest $64: 714-720$
3. Nagai T, Adachi M, Noro N, Yodoi J, Uchino H 1985 T and B lymphocytes with immunoglobulin $\mathrm{E} \mathrm{FC}$ receptors $(\mathrm{Fc} \in \mathrm{R})$ in patients with nonallergic hyperimmunoglobulinemia $\mathrm{E}$ : demonstration using a monoclonal antibody against $F_{c} \epsilon$ R-associated antigen. Clin Immunol Immunopathol 35:261-275

4. Jarret E, Bazin H 1974 Elevation of total serum IgE in rats following helminth parasite infection. Nature 241:613-614

5. Yodoi J, Ishizaka T, Ishizaka K 1979 Lymphocytes bearing Fc receptors for IgE. II. Induction of Fc $\epsilon$-receptor bearing rat lymphocyte by IgE. J Immunol 123:455-462

6. Suemura M, Yodoi J, Hirashima M, Ishizake K 1980 Regulatory role of IgEbinding factors from rat $\mathrm{T}$ lymphocytes. I. Mechanism of enhancement of IgE response by IgE-potentiating factor. J Immunol 125:148-154

7. Young MC, Leung DYM, Geha RS 1984 Production of IgE-potentiating factor in man by $T$ cell lines bearing Fc receptors for IgE. Eur J Immunol 14:871878

8. Sarfati M, Rector E, Wong K, Rubio-Trujillo M, Sehon AH, Delespesse G 1984 In vitro synthesis of IgE by human lymphocytes. II. Enhancement of the spontaneous IgE synthesis by IgE-binding factors secreted by RPMI 8866 lymphoblastoid B cells. Immunology 53:197-205

9. Sarfati M, Rector E, Wong K, Rubio-Trujillo M, Sehon AH, Delespesse G 1984 In vitro synthesis of IgE by human lymphocytes. III. Enhancement of the spontaneous IgE synthesis by IgE-potentiating activity of culture supernatants from Epstein-Barr virus (EBV) transformed B cells. Immunology 53:207-214

10. Kim K-M, Tanaka M, Yoshimura T, Katamura K, Mayumi M, Mikawa $\mathrm{H}$ 1987 Regulation of IgE receptor expression on human peripheral blood lymphocytes by lymphocytosis promoting factor (LPF), lectins and dexamethasone. Clin Exp Immunol 68:418-426

11. Huff TF, Uede T, Iwata M, Ishizaka K 1983 Modulation of biologic activity of IgE-binding factors. III. Switching on a $T$ cell hybrid clone from the formation of IgE-suppressive factor to the IgE-potentiating factor. J Immunol 131:1090-1095

12. Delespesse G, Sarfati M, Rubio-Trujillo M, Wolowiec T 1986 IgE receptors on human lymphocytes. III. Expression of IgE receptors in mitogen-stimulated human mononuclear cells. Eur J Immunol 16:1043-1047

13. Yodoi J, Ishizaka K 1980 Induction of Fc $\epsilon$-receptor bearing cells in vitro in human peripheral lymphocytes. J Immunol 124:934-938

14. Suemura M, Kikutani H, Barsumian EL, Hattori Y, Kishimoto S, Sato R, Maede A, Nakamura H, Owaki H, Hardy RR, Kishimoto T 1986 Monoclonal anti-Fc $\epsilon$ receptor antibodies with different specificities and studies on the expression of Fce receptors on human $B$ and $T$ cells. $J$ Immunol 137:1214-1220

15. Yodoi J, Hirashima M, Ishizaka K 1981 Lymphocytes bearing Fc receptors for IgE. VI. Suppressive effect of glucocorticoids on the expression of Fce receptors and the nature of IgE-binding factors. J Immunol 127:471-476

16. Böyum A 1968 Separation of leukocytes from blood and bone marrow. Scand J Clin Lab Invest 21(suppl 97):77-89

17. Noro N, Yoshioka A, Adachi M, Yasuda K, Masuda T, Yodoi J 1986 Monoclonal antibody (H107) inhibiting IgE binding to Fc $\in$ R human lymphocytes. J Immunol 137:1258-1263

18. Johanson SGO 1967 Raised levels of a new immunoglobulin class (IgND) in asthma. Lancet 2:951-953

19. Delespesse G, Sarfati M, Rubio-Trujillo M, Wolowiec T 1986 IgE receptors on human lymphocytes. II. Detection of cells bearing IgE receptors in unstimulated mononuclear cells by means of a monoclonal antibody. Eur J Immunol 16:815-821

20. Ishizaka K, Sandberg K 1981 Formation of IgE-binding factors by human $T$ lymphocytes. J Immunol 126:1692-1696 